\title{
RUSSIA'S FOREIGN TRADE IN DECEMBER 2015
}

\author{
N.Volovik
}

In December 2015, Russian foreign trade outlook was determined by a reduction of the world prices on commodities, mainly on oil, and correlated with it ruble's depreciation. Import volume was shrinking by higher rates compared to export decline rates due to slowdown of economic growth and ruble's devaluation as well as amid imposed international trade sanctions. As a result, in 2015 trade balance remained positive.

In December 2015, Russian foreign trade turnover totaled \$ 45.9bn, which was below similar indicator in 2014 by $27.1 \%$. Exports constituted $\$ 28.4 \mathrm{bn}$ down $26 \%$ against December 2014. Imports came to $\$ 17.4$ bn down $28.8 \%$ against the same indicator in 2014 . Trade balance contracted by $21 \%$ to $\$ 11 \mathrm{bn}$.

Export contraction is still conditioned by the fall of price on major goods of Russian export in the world markets. Since the turn of the year, Bloomberg Commodity Index down $24.4 \%$ (from 103.86 points on January 2015 down to 78.56 points on 31 December 2015), which is the worst indicator since 2008.

Bloomberg Petroleum Index (BCOMPE) down 13\% in December 2015 against November and during the year shrank by $39 \%$. There is glut on the global crude oil market, supply exceeds demand by around $2 \mathrm{mn}$ barrels per day. Crude oil quotations are at the bottom low since early 2009. According to the International Energy Forecasts (IEA) ${ }^{1}$, total oversupply of crude oil between 2014 and 2017 will hit $1.5 \mathrm{mn}$ barrels. The IEA also considers that in 2017 demand will exceed supply by $1.1 \mathrm{mn}$ barrels per day.

In December 2015, monthly Brent price averaged \$37.72 per barrel down $39.5 \%$ against December 2014. Average monthly TWI price down $37.2 \%$ to $\$ 37.23$ per barrel.

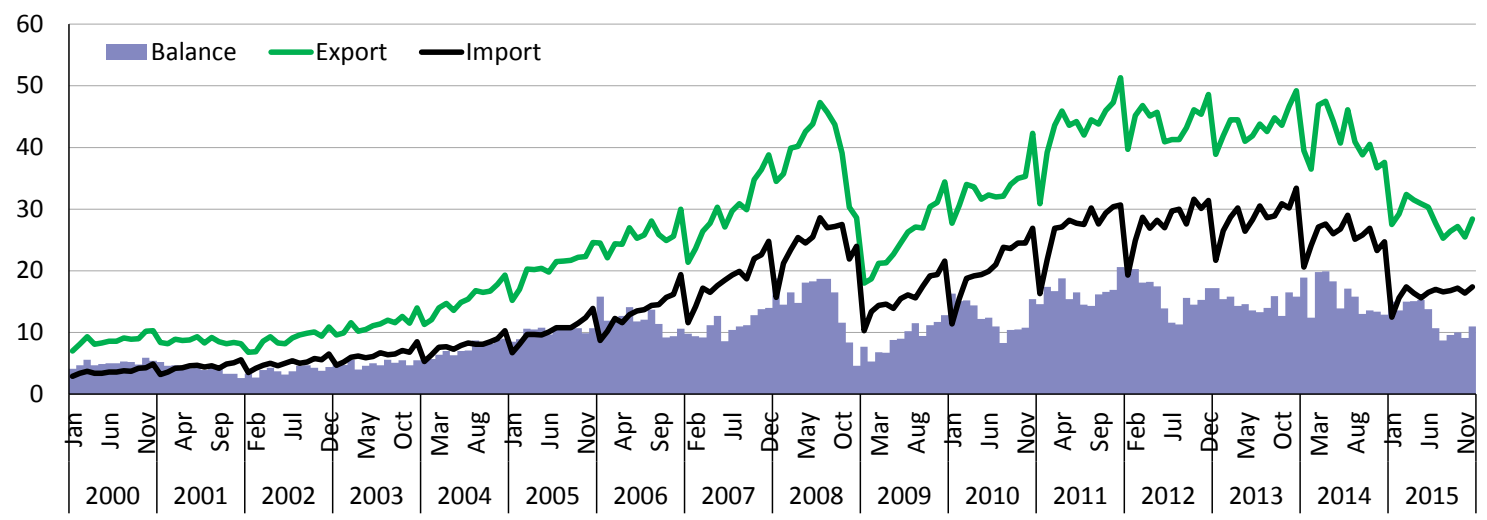

Source: CB RF.

Fig. 1. Russia's key foreign trade indicators (USD billion)

1 https://www.iea.org/newsroomandevents/pressreleases/2016/february/global-oil-supply-growth-plunging-with-us-taking-biggest-hit-for-now.html 
In December 2015, Urals price down 40.2\% against December 2014 and came to $\$ 28.38$ per barrel. Annual average price of Urals in 2015 down $47.5 \%$ compared to 2014 and hit $\$ 51.23$ per barrel.

Average price of crude oil for the period from 15 January to 14 February 2016 inclusive came to $\$ 28.38$ per barrel or $\$ 207.2$ per ton. Hereby, according to the Ministry of Economic Development (MED) of Russia of February 18,2016 , since March 1, 2016, oil export duty will decrease by $24 \%$ and will come to $\$ 39.5$ per ton against $\$ 52$ per ton a month before. Export duty on high viscosity oil from 1 march will decline by $\$ 1.7-$ from $\$ 5.9$ per ton to $\$ 4.2$ per ton. Export duty on straight-run gasoline (naphtha) will decline from $\$ 36.9$ per ton to $\$ 28$ per ton, on automobile (commercial) gasoline - from $\$ 31.7$ per ton to $\$ 24$ per ton. Export duty on other light petroleum products and lubricants will fall from $\$ 20.8$ per ton to $\$ 15.8$ per ton, and export duty on dark petroleum products less lubricants and coke will reduce from $\$ 42.6$ per ton to $\$ 32.2$ per ton, and export duty on coke will move down from $\$ 3.3$ per ton to $\$ 2.5$ per ton.

According to the London Metal Exchange in December 2015 against November 2015, price of copper fell by $3.7 \%$, nickel down $5.8 \%$, and aluminum up $2 \%$. In comparison with December 2014, price of nickel down $45.4 \%$, aluminum down $21.9 \%$, copper down $27.9 \%$. In 2015 , price of aluminum fell against 2014 by $10.9 \%$, price of copper down $19.7 \%$, and price of nickel down $26.6 \%$.

In December 2015, the Food Price Index FAO averaged 154.1 points down 1.5 points (1.0\%) against its revised November index, which resulted from decline of prices on practically all food commodities, which are used in its calculation less sugar and vegetable oils. Average annual Index came to 164.1 points down by nearly $19 \%$ than in 2014 . Thus, decline of the Food Price Index goes on for the fourth months in a row. Falling prices on foodstuffs registered in 2015 is explained, first of all, by availability of significant stocks and slack demand on the global markets as well as by strengthening of the US dollar.

In 2015, Russian export contracted compared to 2014 by $31.6 \%$ to $\$ 340.3 \mathrm{bn}$. Increase of export effectiveness due to the ruble's devaluation has contributed to the growth of exports in value terms. For example, in 2015 compared to 2014, in quantitative terms export of crude oil went up by $9.4 \%$, petroleum products up $4.1 \%$, natural gas up $7.5 \%$, mineral fertilizers potassium up $6.9 \%$, mineral fertilizers mixed up $7.1 \%$, processed timber up $10.7 \%$,

Table 1

MONTHLY AVERAGE GLOBAL PRICES IN NOVEMBER THEN-YEAR

\begin{tabular}{|c|c|c|c|c|c|c|c|c|c|c|c|}
\hline & 2005 & 2006 & 2007 & 2008 & 2009 & 2010 & 2011 & 2012 & 2013 & 2014 & 2015 \\
\hline Brent USD/bbl. & 56.4 & 63.1 & 90.64 & 72.77 & 75.26 & 91.8 & 107.91 & 109.68 & 110.67 & 62.33 & 37.72 \\
\hline $\begin{array}{l}\text { Natural gas*, } \\
\text { USD/1 mil- } \\
\text { lion BTU }\end{array}$ & 7.49 & 8.92 & 9.49 & 15.5 & 8 & 8 & 3 & 7 & 11 & 9.83 & 6.10 \\
\hline Copper, USD/t & 78.0 & 6643.9 & 580.5 & 3072 & 982.0 & 9111 & 7565 & 7966.8 & 7214.9 & 6446.5 & 4638. \\
\hline Aluminum, & 248.0 & 2816.9 & 2380.2 & 1490.4 & 2179.7 & 2321.5 & 2022 & 2086.8 & 1739.8 & 1909.5 & 14 \\
\hline Nickel, USD/t & 3423 & 34578 & 26003 & 686.4 & 17066 & 24946 & 18267 & 17449 & 13925 & 15962 & 8707.8 \\
\hline
\end{tabular}

* European market, average contract price, franco-border.

Source: World Bank. 
conventional plywood up $12.2 \%$, wood pulp up $10.1 \%$, denim up $6.6 \%$, ferrous metals up $7.5 \%$, refined copper up $94.1 \%$ and untreated aluminum up $18.9 \%$.

However, growth of Russian export in quantitative terms failed to offset losses incurred from the fall of average export prices on practically all exported commodities. Significant contraction of export in value terms was observed on all commodities of extended nomenclature. Worst hit was the group of commodities 'Mineral products', which contracted by 6.7 points to $63.8 \%$. Export of metals and metal products shrank by $18.6 \%$, wood and paper products - by $15.5 \%$, and chemical products - by $13 \%$.

By the period-end for 2015 compared to 2014, Russian export pattern suffered the following changes: with the reduction of share of mineral products the share of metals and metal products, machines, equipment and means of transport, chemical products and rubber, foodstuffs and agricultural raw materials, timber and pulp and paper products went up. The share of high tech products went up and reached $10.1 \%$ of the overall export volume (in 2014 it reached 8.5\%).

In 2015 compared to 2014 , Russian export contracted by $37 \%$ to $\$ 194.1 \mathrm{bn}$. Decline of import was observed across all grand positions of products nomenclature. Highest reduction was observed regarding import of passenger cars (down 50.5\%) and trucks (down 57\%), flying machines (by 56.2\%), and components of motor means of transport 9 by $45.1 \%$ ).

In early August 2014, Russia introduced a food products ban from countries, which imposed sanctions on Russia: USA, EU countries, Canada, Australia and Norway. The following products were banned: beef, pork, poultry, sausage, fish, vegetables, fruit, dairy products and other products. In 2015 compared to 2014 , import of banned products moved down in value terms by $46 \%$ to $\$ 7.6 \mathrm{bn}$. Highest decline was observed in relation to meat (cattle and pork), dairy products (first of all, cheeses and butter), apples and pears, fresh and frozen fish.

Import of many consumer goods fell due to the fall of real incomes of the population.

In the Russian import pattern the ration of the following products went up: chemical products and rubber, fuel and energy products, foodstuffs and agricultural raw materials, textiles, textile products and footwear, fell the share of machines, equipment and means of transport, metals and metal products, share of timber and paper products remained unchanged.

In 2015 compared to 2014, regional pattern of Russian foreign trade saw a reduction of the share of EU countries (from $48.1 \%$ to $44.8 \%$ ). The share of $\mathrm{CIS}$ countries remained at 2014 level of $12.5 \%$. At the same time, the share of APEC member states went up from $26.9 \%$ to $28.1 \%$.

In 2015, China remained principal trade partner of Russia, whose share in Russian trade turnover went up to $12.1 \%$ (in $2014-11.3 \%$ ). Germany was on the second place but its share fell in 2015 to $8.7 \%$ (in $2014-8.9 \%$ ). Netherlands took the third place with $8.4 \%$ (in $2014-9.3 \%$ ).

During 2015, the share of all EU members went on falling in the RF foreign trade turnover. Highest hit was turnover with the following countries: Estonia down 49.6\%, Sweden down 46.7\%, Slovenia down 42.4\%, Latvia down $44.9 \%$, and Great Britain down 41.9\%. Though trade flow between Russia and EU fell, the European Union remains the major partner of the Russian Federation. However, relations are complicated by many factors: both internal issues of 
CHANGE OF IMPORT OF MAJOR PRODUCTS IN 2015 COMPARED TO 2014, \%

\begin{tabular}{|c|c|c|c|c|}
\hline Code & Наименование товара & $\begin{array}{c}\text { Quantitative } \\
\text { volume }\end{array}$ & $\begin{array}{l}\text { Value } \\
\text { volume }\end{array}$ & $\begin{array}{c}\text { Average } \\
\text { contract prices }\end{array}$ \\
\hline $0201-0204$ & Fresh and frozen meat & 73.5 & 57.8 & 78.6 \\
\hline 0207 & Fresh and frozen poultry & 56.0 & 45.4 & 81.1 \\
\hline $0302-0304$ & Fresh and frozen fish & 61.7 & 52.8 & 85.5 \\
\hline 0402 & Milk and concentrated cream & 110.6 & 65.6 & 59.4 \\
\hline 0405 & Butter & 64.1 & 42.0 & 86.1 \\
\hline 0805 & Citrus & 93.1 & 80.2 & 80.0 \\
\hline 0901 & Coffee & 101.4 & 89.4 & 88.2 \\
\hline 0902 & Tea & 100.3 & 98.8 & 98.5 \\
\hline 10 & Grains & & 62.8 & \\
\hline 1001 & Wheat and muslin & 101.7 & 76.8 & 75.5 \\
\hline 1005 & Corn & 83.1 & 64.9 & 78.1 \\
\hline 1512 & Vegetable oil & 37.5 & 34.5 & 92.1 \\
\hline $170112-170114$ & Raw sugar & 76.1 & 68.3 & 89.8 \\
\hline 1701991000 & White sugar & 156.3 & 90.5 & 57.9 \\
\hline 1801 & Cacao beans & 74.4 & 73.5 & 98.7 \\
\hline 1806 & Products containing cacao & 56.0 & 55.2 & 98.6 \\
\hline 22 & Alcoholic and nonalcoholic beverages & & 58.2 & \\
\hline 2402 & Cigarettes and cigars & & 90.6 & \\
\hline $3003-3004$ & Drugs & & 67.3 & \\
\hline $5208-5212$ & Cotton fabrics & 80.2 & 73.6 & 91.7 \\
\hline $61-62$ & Cloths & & 65.9 & \\
\hline 6403 & Leather footwaer & 69.2 & 62.6 & 90.4 \\
\hline 72 & Ferrous metals & 74.2 & 59.1 & 79.6 \\
\hline $84-90$ & Machines and equipment & & 60.0 & \\
\hline 8703 & Autos & 49.8 & 49.3 & 99.2 \\
\hline 8704 & Trucks & 36.7 & 43.0 & 117.0 \\
\hline $9401-9403$ & Furniture & & 54.4 & \\
\hline
\end{tabular}

Source: calculated on FCS data.

economic development of Russia and external ones: differences regarding situation in Ukraine and in Syria, sanctions and countersanctions.

Russian trade deficit developed with 20 countries, whose share in the overall RF trade turnover constitufted $24.2 \%$. The biggest trade deficit Russia has with China $(-\$ 6.3 \mathrm{bn})$, USA $(-\$ 1.9 \mathrm{bn})$, Indonesia $(-\$ 1.1 \mathrm{bn})$, Thailand $(-\$ 0.9 \mathrm{bn})$, Brazil (-\$1.0bn) and Argentina (-\$0.7bn). 